\title{
UJI KUANTITATIF KADAR ZAT BESI DALAM TUMBUHAN KELAKAI DAN PRODUK OLAHANNYA
}

\author{
Nurul Qamariah ${ }^{1}$, Rini Yanti ${ }^{2}$ \\ 1DosenPengajar Program Studi D-III Farmasi, FakultasIlmuKesehatan, \\ UniversitasMuhammadiyahPalangkaraya \\ ${ }^{2}$ Mahasiswa Program Studi D-III Farmasi Fakultas IImu Kesehatan \\ Universitas Muhammadiyah Palangkaraya \\ Email: enqiyu9@gmail.com
}

\begin{abstract}
ABSTRAK
Zat besi memiliki sifat yang tidak dapat diproduksi oleh tubuh, sehinggakita harus mencukupi kebutuhan zat besi dari makanan. Zat besi merupakan unsuryang sangat penting untuk membentuk hemoglobin $(\mathrm{Hb})$. Dalam tubuh, zat besimempunyai fungsi yang berhubungan dengan pengangkutan, penyimpanan danpemanfaatan oksigen dan berada dalam bentuk hemoglobin, mioglibin ataucytochrom. Untuk memenuhi kebutuhan guna pembentukan hemoglobin, sebagianbesar zat besi yang berasal dari pemecahan sel darah merah akan dimanfaatkankembali baru kekurangannya harus dipenuhi dan diperoleh melalui makanan.

Pemilihan bahan makanan yang mengandung zat besi dapat diperolehmelalui tumbuhan berupa tumbuhan kelakai, dikarenakan tumbuhan kelakaimerupakan tumbuhan yang banyak dikonsumsi masyarakat Kalimantan Tengah,murah, persediaannya banyak, dapat tumbuh dimana-mana, mudah didapatkandan mengandung zat besi sebagaimana dari hasil penelitian Maharani et al., sertaproduk olahannya sering dijadikan oleh-oleh khas Kalimantan Tengah. Adapunproduk olahan kelakai oleh masyarakat Kalimantan Tengah biasa diolah menjadisayur oseng kelakai, keripik kelakai, peye kelakai, kerupuk kelakai, stik kelakaidan lain-lainnya yang berbahan dasar tumbuhan kelakai itu sendiri.

Penelitian ini menggunakan analisis kuantitatif dengan metode volumetri yaitu titrasi permanganometri, dengan pendekatan laboratorium yang dilakukanmelalui serangkaian percobaan. Sampel yang digunakan dalam penelitian iniadalah tumbuhan kelakai yang diperoleh pada Pasar Besar Kota Palangka Rayadan produk olahannya pada dua industri rumahan yang terdapat di Kota PalangkaRaya. Hasil penelitian yang telah dilakukan menunjukkan bahwa kadar zatbesi pada daun tanaman kelakai segar sebesar $3,285 \%$ atau setara dengan $3285 \mathrm{mg} / 100 \mathrm{~g}$. Sedangkan kadar zat besi pada olahannya diperoleh hasil berupakeripik kelakai 1 sebesar 2,235\% atau setara dengan $2235 \mathrm{mg} / 100 \mathrm{~g}$ dan keripikkelakai 2 sebesar 1,925\% atau setara dengan $1925 \mathrm{mg} / 100 \mathrm{~g}$. Sehingga dapatdisimpulkan kadar zat besi pada tumbuhan kelakai cukup tinggi dan zat besidalam keripik kelakai sendiri dapat digunakan masyarakat untuk memenuhikebutuhan zat besi hariannya.
\end{abstract}

Kata Kunci:Zat Besi, Tumbuhan Kelakai, Keripik Kelakai, Titrasi Permanganometri 


\section{PENDAHULUAN}

Bahan makanan mengandung berbagai zat gizi yang diperlukantubuh untuk melakukan berbagai aktifitas. Zatzat gizi tersebut adalahkarbohidrat, lemak, protein, vitamin, mineral, dan air.

Kandungan giziutama dalam buah dan sayuran adalah vitamin dan mineral. Dimana salahsatu mineral dalam buah dan sayuran adalah zat besi (Fe) (Wirakusumah,2013).

Zat besi memiliki sifat yang tidak dapat diproduksi oleh tubuh,sehingga kita harus mencukupi kebutuhan zat besi dari makanan. Zat besimerupakan unsur yang sangat penting untuk membentuk hemoglobin $(\mathrm{Hb})$.Dalam tubuh, zat besi mempunyai fungsi yang berhubungan denganpengangkutan, penyimpanan dan pemanfaatan oksigen dan berada dalambentuk hemoglobin, mioglibin atau cytochrom. Untuk memenuhi kebutuhanguna pembentukan hemoglobin, sebagian besar zat besi yang berasal daripemecahan sel darah merah akan dimanfaatkan kembali, barukekurangannya harus dipenuhi dan diperoleh melalui makanan. Taraf gizibesi bagi seseorang sangat dipengaruhi oleh jumlah konsumsinya melaluimakanan, bagian yang diserap melalui saluran pencernaan, cadangan zatbesi dalam jaringan eksresi dan kebutuhan tubuh (Wijatmadi dan Adriani,2012).

Menurut FAO/WHO menganjurkan bahwa jumlah zat besi yangharus dikonsumsi sebaiknya berdasarkan jumlah kehilangan zat besi daridalam tubuh. Kandungan zat besi dalam tubuh wanita adalah sekitar $35 \mathrm{mg} / \mathrm{kg}$ BB dan pada lakilaki $50 \mathrm{mg} / \mathrm{kg} \mathrm{BB}$, dimana $70 \%$ terdapat di dalamhemoglobin dan $25 \%$ merupakan zat besi cadangan yang terdapat dalamhati, limpa, dan sumsum tulang. Jumlah zat besi yang dapat disimpan dalamtubuh $0,5-1,5 \mathrm{~g}$ pada laki-laki dewasa dan 0,3-1,0 g pada wanita dewasa.

Pembuangan zat besi keluar tubuh terjadi melalui beberapa jalandiantaranya melalui keringat 0,2-1,2 mg/hari, air seni $0,1 \mathrm{mg} / \mathrm{hari}$, danmelalui feses dan menstruasi 0,5-1,4 mg/hari (Wijatmadi dan Adriani,2012).

Zat besi memiliki sifat yang tidak dapat diproduksi oleh tubuh,sehingga kita harus mencukupi kebutuhan zat besi dari makanan (Wijatmadi dan Adriani, 2012).

Adapun makanan yang mengandung zat besi, salah satunya adalah kelakai. Kelakai adalah tumbuhan memiliki nama latinStenochlaena palustris yang hidup di daerah rawa gambut, air tawar danhutan belukar. Sebagaimana diketahui dalam penelitian Maharani et al., (2005) terbukti bahwa tumbuhan kelakai yang berasal dari Banjarmasin ini mengandung mineral zat besi sebesar $291,316 \mathrm{mg} / 100 \mathrm{~g}$ pada daun dansebesar $221,443 \mathrm{mg} / 100 \mathrm{~g}$ pada batangnya. Penelitian tersebut dilakukan dengan menggunakan metode analisis spektrofotometri.

Berdasarkan penelitian tersebut, maka diasumsikan produk olahankelakai 
pun dianggap mengandung zat besi.

Dimana produk olahan kelakaioleh masyarakat Kalimantan Tengah biasa diolah menjadi sayur osengkelakai, keripik kelakai, peye kelakai, kerupuk kelakai, stik kelakai dan lainnyayang berbahan dasar tumbuhan kelakai itu sendiri. Namun belumbanyak publikasi penelitian mengenai kandungan zat besi yang ada padatumbuhan maupun produk olahan kelakai yang berasal dari KalimantanTengah.

\section{METODE PENELITIAN}

Penelitian ini dilakukan di Laboratorium Farmakologi Fakultas IlmuKesehatan Universitas Muhammadiyah Palangkaraya. Dengan waktupelaksanaan dilakukan mulai dari 1 November 2015 sampai dengan 7Desember 2015.

\section{Metode / Pendekatan Penelitian}

Metodologi yang digunakan dalam penelitian ini adalah penelitianeksperimen atau percobaan (experiment research) dengan pendekatanlaboratorium yang dilakukan melalui serangkaian percobaan. Bertujuanuntuk mengetahui suatu gejala atau pengaruh yang timbul sebagai akibat dari adanya perlakuan tertentu (Notoatmodjo, 2010).

\section{Populasi dan Sampel Penelitian}

\section{Populasi Penelitia}

Populasi yang termasuk pada penelitian ini adalah tumbuhankelakai
(Stenochlaena palustris) dan produk olahan berupa keripikkelakai yang ada di kota Palangka Raya, Kalimantan Tengah.

\section{Sampel Penelitian}

Sampel tumbuhan kelakai diperoleh dari Pasar Besar KotaPalangka Raya, Kalimantan Tengah. Sedangkan olahan keripik kelakaidiperoleh dari industri rumahan yaitu di Jl. Majapahit No.5B RT 02 RW08 Komplek Borobudur dan Jl. Kecipir No.12 RT 01 RW 03.Pengambilan sampel dilakukan dengan teknik purposive samplingdimana kriteria yang ditentukan adalah industri rumahan keripik kelakaiyang melakukan produksi keripik kelakai secara kontinu dan menetap dengan bahan baku berasal dari tumbuhan kelakai yang dijual di PasarBesar Kota Palangka Raya, Kalimantan Tengah.

\section{Persiapan Larutan}

\section{Pembuatan KMnO4 0,1 N}

Melarutkan lebih kurang 3,3 gram kalium permanganat $P$ dalam $1000 \mathrm{~mL}$ air dalam labu, dan mendidihkan larutan selama lebihkurang 15 menit. Menutup labu dan membiarkan selama tidak kurangdari 2 hari, lalu menyaring melalui penyaring kaca masir berporositashalus. Jika perlu lapisi dasar penyaring kaca masir dengan wol kaca(FI IV, 1995). 


\section{Standarisasi KMnO4}

Menimbang dengan seksama lebih kurang 200 mg asam oksalatyang telah dikeringkan pada suhu $110 \square \mathrm{C}$ hingga bobot tetap dan larutkandalam erlenmeyer sebanyak $100 \mathrm{~mL}$ aquadest. Lalu menambahkan 7 mLasam sulfat $P$ panaskan hingga suhu lebih kurang 70 $\square$ C. Dalam keadaanpanas, menambahkan perlahan-lahan larutan dalam erlenmeyer denganKMnO4 0,1 N sambil mengaduk hingga warna merah muda pucat yangmantap selama 15 detik. melakukan secara duplo (dilakukan pengulangan sebanyak dua kali). Menghitung normalitas larutan (FI IV, 1995).

Catatan : suhu larutan selama titrasi tidak kurang dari $60 \square C$

\section{Penentuan Kadar Besi}

\section{Sampel}

Menimbang sebanyak 5 gram sampel. Menghaluskan sampeldalam mortar hingga homogen atau menjadi bubur. Lalu menambahkan aquadest secukupnya dan saring dengan kasa. Hasilsaringan dalam labu ukur $100 \mathrm{~mL}$ lalu ditambahkan aquadest sampaitanda batas $100 \mathrm{~mL}$ dan kocok. Mengambil filtratnya sebanyak 100 $\mathrm{mL}$, memasukkan ke dalam erlenmeyer $250 \mathrm{~mL}$ dan memanaskanhingga mencapai suhu $70 \square$ C. Dalam keadaan panas, menambahkanperlahan-lahan larutan dalam erlenmeyer dengan $\mathrm{KMnO} 4$ 0,1 $\mathrm{N}$ sambildiaduk hingga warna merah muda yang mantap selama 15
detik.Melakukan secara duplo (dilakukan pengulangan sebanyak dua kali).

Menghitung kadar besi dalam sampel.

\section{Teknik Analisis Data}

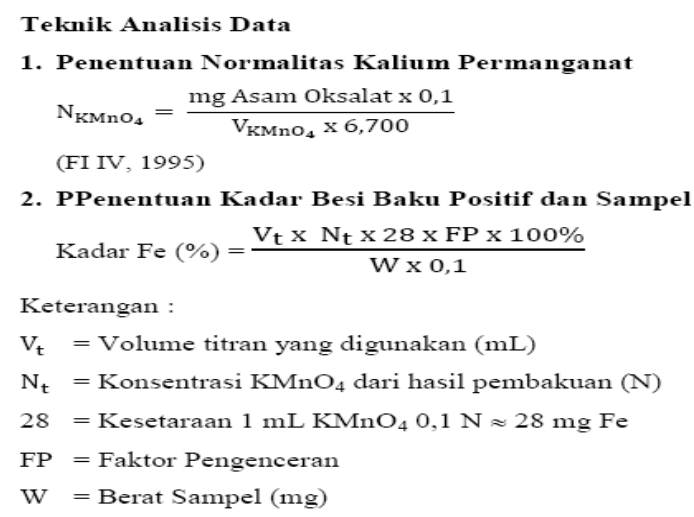

\section{HASIL DAN PEMBAHASAN}

\begin{tabular}{|c|c|c|c|c|c|c|}
\hline \multicolumn{7}{|c|}{$\begin{array}{l}\text { Hasil Penelitian } \\
\text { Tabel 2. Hasil Pembakuan }\end{array}$} \\
\hline Bahan & $\begin{array}{r}\text { Berat Bah: } \\
\text { yang Diguna } \\
(\mathbf{g})\end{array}$ & & $\begin{array}{r}\mathrm{V} \mathrm{T} \\
\mathrm{KM} \\
(\mathrm{n}\end{array}$ & $\begin{array}{l}\text { itran } \\
\mathrm{nO}_{4} \\
\mathrm{~L})\end{array}$ & Ket. & $\begin{array}{l}\text { Rata } \\
\text { Rata }\end{array}$ \\
\hline $\mathrm{KMnO}_{4}$ & \multicolumn{2}{|c|}{$3,3251 \mathrm{~g}$} & \multicolumn{2}{|c|}{$1000 \mathrm{~mL}$} & $0,0964 \mathrm{~N}$ & - \\
\hline \multirow{2}{*}{ Asam Oksalat } & \multicolumn{2}{|l|}{$0,1134 \mathrm{~g}$} & \multicolumn{2}{|c|}{$17.6 \mathrm{~mL}$} & $0,0962 \mathrm{~N}$ & \multirow{2}{*}{$0,0964 \mathrm{~N}$} \\
\hline & \multicolumn{2}{|l|}{$0,1047 \mathrm{~g}$} & \multicolumn{2}{|c|}{$16,2 \mathrm{~mL}$} & $0,0965 \mathrm{~N}$ & \\
\hline \multicolumn{7}{|c|}{ Tabel 3. Kadar Sampel } \\
\hline \multirow{2}{*}{ Bahan } & \multirow{2}{*}{$\begin{array}{l}\text { Berat Bahan } \\
\text { yang } \\
\text { Digunakan (g) }\end{array}$} & \multirow{2}{*}{\multicolumn{2}{|c|}{$\underset{\mathrm{KMnO}}{\mathrm{V}}$}} & \multicolumn{2}{|c|}{ Kadar Fe } & \multirow{2}{*}{$\begin{array}{r}\text { Rata-Rata } \\
(\mathbf{m g} / \mathbf{1 0 0} \mathbf{g})\end{array}$} \\
\hline & & & & $\%$ & $\mathrm{mg} / \mathbf{1 0 0 \mathrm { g }}$ & \\
\hline \multirow{2}{*}{$\begin{array}{l}\text { Tumbuhan } \\
\text { Kelakai }\end{array}$} & $5.0228 \mathrm{~g}$ & & $\mathrm{~mL}$ & 3.28 & 3280 & \multirow{2}{*}{3285} \\
\hline & $5,0829 \mathrm{~g}$ & & $\mathrm{~mL}$ & 3,29 & 3290 & \\
\hline \multirow{2}{*}{$\begin{array}{c}\text { Keripik } \\
\text { Kelakai } 1\end{array}$} & $5,0098 \mathrm{~g}$ & & $\mathrm{~mL}$ & 2,21 & 2210 & \multirow{2}{*}{2235} \\
\hline & $5,0127 \mathrm{~g}$ & & $\mathrm{~mL}$ & 2,26 & 2260 & \\
\hline \multirow{2}{*}{$\begin{array}{c}\text { Keripik } \\
\text { Kelakai } 2\end{array}$} & $5,0745 \mathrm{~g}$ & & $\mathrm{~mL}$ & 1,91 & 1910 & \multirow{2}{*}{1925} \\
\hline & $5.0813 \mathrm{~g}$ & & $\mathrm{~mL}$ & 1.94 & 1940 & \\
\hline
\end{tabular}

Penelitian uji kuantitatif kadar zat besi dalam tumbuhan kelakai dankeripik kelakai ini menggunakan metode titrasi permanganometri. Ujikuantitatif adalah penetapan berapa banyak suatu zat tertentu yangterkandung dalam suatu sampel (Day dan Underwood, 2001), sementarametode titrasi permanganometri merupakan suatu analisis yangmenggunakan $\mathrm{KMnO} 4$ sebagai pentiter dan indikator sehingga disebutsebagai autoindikator. Analisis 
kadar zat besi pada keripik kelakai inidilakukan agar mengetahui kadar zat besi tumbuhan kelakai dan keripikkelakai.

Zat besi sendiri sangat dibutuhkan setiap orang dari berbagaikalangan baik itu berupa bayi, anak-anak, remaja, dewasa maupun manuladengan jumlah konsumsi yang tepat maka akan tepat pula asupan kadar zat besi yang dibutuhkan dalam tubuh sehingga mencegah terjadinya penyakitanemia, defisiensi ataupun kelebihan zat besi.Di Indonesia, anemia defisiensi zat besi menjadi pemicu penurunannya konsentrasi belajar dan perkembangan tumbuh kembang anakdi Indonesia sehingga menurunkan produktivitas bagi anak Indonesia.Bukan hanya pada anakanak, anemia ataupun defisiensi zat besi seringterjadi pada wanita yang sedang haid (Mann dan Truswell, 2014) danmelahirkan akibat kekurangan zat besi yang cukup banyak (Muchtadi,2009). Sementara itu, kelebihan zat besi sendiri dapat menyebabkan pemicuberbagai penyakit akibat tertimbun (terakumulasi) di dalam tubuh sepertikondisi melemah, kerusakan hati, jantung, pankreas dan kemungkinankerusakan organ lain, dan lain-lain (Linder, 2006).

Pemilihan sampel berupa tumbuhan kelakai dan keripik kelakaidilakukan karena tumbuhan ini banyak dikonsumsi sebagai makanan sehari-harimasyarakat Kalimantan khususnya daerah Kalimantan Tengah, danjuga banyak diolah menjadi keripik kelakai sebagai camilan ataupun sebagaioleh-oleh khas Kalimantan Tengah yang diperdagangkan.

Dalam penelitian ini, standarisasi larutan penitrasi $\mathrm{KMnO} 4$ dilakukandengan standar primer asam oksalat. Hasil standarisasi pertama menunjukannormalitas larutan $\mathrm{KMnO} 4$ sebesar 0,0962 N, sedangkan yang kedua sebesar0,0965 N. Sehingga didapat normalitas larutan $\mathrm{KMnO} 4$ sebesar 0,0964 N.

Pada proses standarisasi dilakukan pemanasan asam oksalat dalamoven selama 1 jam dengan suhu $110 \square \mathrm{C}$ hal ini bertujuan untukmenghilangkan molekul air (Gandjar, 2013) dan sesuai dengan ketetapanperlakuan untuk standarisasi KMnO4 (FI IV, 1995). Sementara itu,penambahan asam sulfat pekat bertujuan sebagai katalis yang memberikansuasana asam pada larutan, hal ini dilakukan agar mempercepat terjadinyareaksi sehingga TAT akan lebih mudah untuk diamati dan reaksi $\mathrm{H} 2 \mathrm{SO} 4$ Ptersebut tidak menghasilkan prodak dan tidak bereaksi dengan titran (Daydan Underwood, 2001). Kemudian pemanasan $70 \square$ C karena untukmempercepat reaksi karena reaksi $\mathrm{KMnO} 4$ yang akan berjalan lambat padasuhu ruangan, sehingga akan lebih banyak lagi kesulitan yang akanditemukan dalam penggunaan reagen $\mathrm{KMnO} 4$ atau selama berjalannyaproses titrasi (Day dan Underwood, 2001).

Sementara pada hasil kadar zat besi sampel berupa daun tumbuhankelakai 
segar pertama adalah 3,28\% atau setara dengan $3280 \mathrm{mg} / 100 \mathrm{~g}$ dankadar zat besi daun tumbuhan kelakai segar kedua adalah 3,29\% atau setaradengan 3290 $\mathrm{mg} / 100 \mathrm{~g}$. Sehingga didapatkan rata-rata kadar zat besi dauntumbuhan kelakai segar yaitu $3,285 \%$ atau setara dengan $3285 \mathrm{mg} / 100 \mathrm{~g}$.

Adapun hasil kadar zat besi sampel pada keripik kelakai 1 ke-1 adalah2,21\% atau setara dengan $2210 \mathrm{mg} / 100 \mathrm{~g}$ dan keripik kelakai 1 ke-2 adalah2,26\% atau setara dengan $2260 \mathrm{mg} / 100 \mathrm{~g}$. Sehingga didapatkan rata-ratakadar zat besi keripik kelakai 1 yaitu 2,235\% atau setara dengan $2235 \mathrm{mg} / 100 \mathrm{~g}$. Lalu untuk kadar zat besi keripik kelakai 2 ke-1 adalah 1,91\%atau setara dengan $1910 \mathrm{mg} / 100 \mathrm{~g}$ dan keripik kelakai 2 ke-2 adalah 1,94\%atau setara dengan 1940 mg/100 g. Sehingga ratarata kadar zat besi keripikkelakai 2 adalah $1,925 \%$ atau setara dengan $1925 \mathrm{mg} / 100$ g.

Dimana hasil warna titrasi pada saat percobaan berawal mula pinknamun setelah beberapa detik berubah menjadi coklat, sebagaimana dapatdilihat pada "lampiran 6" untuk hasil titrasi daun tumbuhan kelakai dan"lampiran 7" untuk hasil titrasi keripik kelakai. Hal ini disebabkan TATpada sampel sudah terjadi dan bila dibiarkan dalam beberapa detik memangakan menghilang, sebagaimana untuk melihat TAT berdasarkan FI IV(1995) adalah terjadi perubahan warna yang tidak hilang selama 15 detik.
Dalam perlakuan titrasi sampel, telah digunakan penyaring kasayang bertujuan untuk memisahkan suatu cairan dari bahan padat yangterdapat pada larutan sampel keripik kelakai dengan porositas kasar dankecepatan penyaringan adalah sangat cepat (Sudarmadji, 2007).

Lalu untuksampel daun tumbuhan kelakai segar sendiri yang digunakan adalah yangmasih muda namun sudah berwarna hijau. Sampel daun tumbuhan kelakaisegar ini dipilih berdasarkan tumbuhan kelakai yang biasanya seringdikonsumsi maupun dijadikan keripik kelakai oleh masyarakat KalimantanTengah, walaupun ada juga yang menggunakan tumbuhan kelakai lebihmuda lagi pada saat tumbuhan kelakai masih berwarna merah keunguan.

Namun, dalam penelitian ini menggunakan tumbuhan kelakai segar yangbiasanya digunakan.Dari hasil kadar zat besi tumbuhan kelakai pada tabel di atas yaitu $3,285 \%$ atausetara dengan $3285 \mathrm{mg} / 100 \mathrm{~g}$, dapat disimpulkan bahwa kandungan zat besidalam kelakai cukup tinggi jika dibandingkan dengan hasil penelitian Maharani et al., (2005) berupa kadar mineral besi daun kelakai yaitu $291,316 \mathrm{mg} / 100$ g. Hal ini dapat disebabkan oleh adanya perbedaan perlakuansampel tumbuhan kelakai dimana pada penelitian Maharani et al.,terlebihdahulu sampel diperlakukan dengan cara sortasi basah, pencucian,perajangan, pengeringan, 
sortasi kering dan terakhir didapatkan ekstraksi.

Sementara pada penelitian ini, sampel tumbuhan kelakai yang sudah dicucidengan air kemudian digerus lalu disaring dan ditambahkan aquades sampai100 $\mathrm{mL}$. Sehingga hasil kadar zat besi pada penelitian ini lebih tinggi karenasampel tumbuhan kelakai yang digunakan lebih segar jika dibandingkan dengan penelitian Maharani et al., karena dalam penelitiannya sudah dilakukan perlakuan terlebih dahulu.

Sementara itu, pada hasil sampel keripik kelakai 1 dan 2 jikadibandingkan dengan hasil sampel tumbuhan kelakai maka kadar zat besikeripik kelakai lebih kecil, hal ini dikarenakan adanya proses pengolahankeripik kelakai berupa penggorengan. Dimana pengaruh suhu yang terlalulama atau terlalu tinggi pada proses pengolahan dapat mengakibatkanhilangnya atau berkurangnya kadar zat besi yang ada di dalam kandungankeripik kelakai (Harris dan Endel, 1989).

Adapun faktor lainnya yang dapatmempengaruhi kadar zat besi pada keripik kelakai adalah akibat lamanyapenyimpanan produk olahan kelakai dari proses pengolahan, pengemasanhingga sampai kepada konsumen (Mann dan Truswell, 2014). Hal inilahyang dapat menyebabkan rendahnya kadar zat besi pada keripik kelakaidaripada tumbuhan kelakai.
Sehingga dapat disimpulkan kadar zat besi pada tumbuhan kelakai cukup tinggi dan walaupun zat besi dalam keripik kelakai sendiri lebih kecildaripada tumbuhan kelakai namun zat besi dalam keripik kelakai sendiridapat digunakan masyarakat untuk memenuhi kebutuhan zat besi hariannya.

\section{KESIMPULAN}

Setelah dilakukan penelitian uji kuantitatif kadar zat besi dalamtumbuhan kelakai dan produk olahannya, diperoleh hasil kadar zat besi pada tumbuhan kelakai sebesar 3285 mg/100 g.Sedangkan kadar zat besi padakeripik kelakai 1 sebesar $2235 \mathrm{mg} / 100 \mathrm{~g}$ dan kadar zat besi pada keripikkelakai 2 sebesar $1925 \mathrm{mg} / 100 \mathrm{~g}$.

\section{DAFTAR PUSTAKA}

Chang, R. 2005. Kimia Dasar: KonsepKonsep Inti Jilid 1 / Edisi Ketiga.Terjemahan Muhammad Abdulkabir Martoprawiro dkk. Editor Lemeda Simarmata dari buku Quantitative Analysis Sixth Edition. Jakarta: PenerbitErlangga.

Day, R. A., dan Underwood, A. L. 2001. Analisis Kimia Kuantitatif EdisiKeenam. Terjemahan lis Sopyan. Editor Hilarius Wibi dan Lemeda Simarmata dari buku Quantitative Analysis Sixth Edition. Jakarta: Penerbit Erlangga. 
Departemen Kesehatan Republik Indonesia. 1995. Farmakope Indonesia Edisi IV.Jakarta.

Fahmawati, Y. 2009. Klasifikasi Tumbuhan. Bandung: Puri Pustaka.Fern, C. S. 2014. Atlas of Living Australia: Stenochlaena palustris (Burm.f.)Bedd. Abstrak.

Ganjar, I. G., dan Rohman, A. 2013. Kimia Farmasi Analisis. Yogyakarta:Pustaka Pelajar.

Harris, R., dan Endel, K. 1989. Evaluasi Gizi Pada Pengolahan Bahan TerbitanKedua. Bandung: Penerbit ITB.

Jannah, M. 2012. Biologi Tumbuhan Lahan Basah: KELAKAI (Stenochlaenapalustris). Abstrak.

Karyadi, D., dan Muhilal. 1996. Kecukupan Gizi yang Dianjurkan. Jakarta: PTGramedia Pustaka Utama.

Linder, M. C. 2006. Biokimia Nutrisi dan Metabolisme.

Penerjemah AminuddinParakkasi dari buku Nutrional Biochemistry and Metabolism. Jakarta:Unversitas Indonesia (UI-Press).

Maharani, D. M., Haidah, S. N., dan Haiyinah. 2005. Studi Potensi Kalakai(Stenochlaenapalustris (Burm.F) Bedd), Sebagai Pangan Fungsional.Abstrak.

Mann, J., dan Truswell, A. S. 2014. Buku Ajar IImu Gizi Edisi 4. Alih
BahasaAndry Hartono. Editor Bahasa Indonesia Mochamad Rachmat. EditorPenyelaras Cahya Ayu Agustin dan Etika Rezkina dari buku Essentials ofHuman Nutrion. Jakarta: EGC. HIm.

Muchtadi, D. 2009. Pengantar IImu Gizi. Bandung: Alfabeta.

Notoatmodjo, S. 2010. Metodologi Penelitian Kesehatan. Jakarta: Rineka Cipta.

Rohman, A., dan Sumantri. 2007. Analisis Makanan. Yogyakarta: Gadjah MadaUniversity Press.

Sediaoetama, A. D. 2010. IImu Gizi untuk Mahasiswa dan Profesi Jilid $I$. Jakarta:PT. Dian Rakyat.

Sudarmadji, S., Haryono, B., dan Suhardi. 2007. Prosedur Analisis untuk BahanMakanan dan Pertanian. Yogyakarta: Liberty.

Surbakti, N. 2011. Smart Thinking For The Better: Penentuan Besi DenganTitrasi permanganometri. Abstrak diunduh dari

http://nantasurbakti.blogspot.com/201 1/12/penentuan-besi-dengantitrasi.html diaksespada 22 November 2014.

Syamsuri, I. 2007. Biologi Jilid 1B untuk SMA Kelas $X$ Semester 2. Jakarta:Penerbit Erlangga.

Watson, D. G. 2009. Analisis Farmasi: Buku Ajar untuk Mahasiswa Farmasi 
dan Praktisi Kimia Farmasi Edisi 2. Terjemahan Wenny R. Syarief. Editor Edisi Bahasa Indonesia Amalia $\mathrm{H}$. Hadinata dari buku Pharmaceutical Analysis: A Textbook for Pharmacy Students and Pharmaceutical Chemists. Jakarta: EGC.

Widodo, D. S., dan Lusiana, R. A. 2010. Kimia Analisis Kuantitatif: Dasar Penguasaan Aspek Eksperimental Edisi Pertama. Yogyakarta: Grah IImu.

Wijatmadi, B., dan Adriani, M. 2012. Pengantar Gizi Masyarakat Edisi Pertama.Jakarta: Kencana.

Winarno, F. G. 1991. Kimia Pangan dan Gizi. Jakarta: PT Gramedia PustakaUtama.

Wirakusumah, E. S. 2013. Jus Buah dan Sayuran. Jakarta: Penebar Plus+. 